\title{
Pergeseran Kekuatan Perbankan di Indonesia
}

\author{
Oleh Sutrisno
}

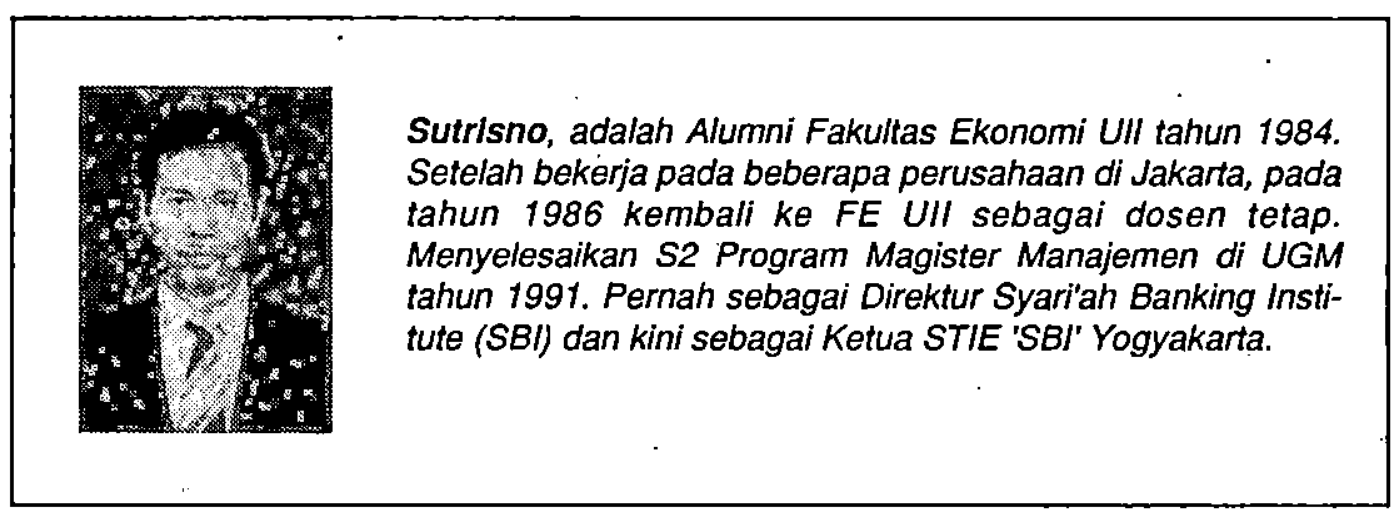

Pendahuluan

Dunia perbankan di Indonesia saat ini dibandingkan dengan satu dasa warsa yang lalu sangat jauh berbeda. Pada sepuluh tahun lalu, perbankan Indonesia masih banyak dicampur tangani oleh pemerintah, sehingga pengelolaannyapun kurang profesional. Dana masyarakat yang bisa dihimpun sangat sedikit akibat aturan reserve requirement yang terlalu besar, yakni $15 \%$.

Perubahan struktur perbankan secara radikal tersebut diawali dengan turunnya paket kebijaksanaan tertanggal 27 Oktober 1988 atau sering disebut Pakto. Paket kebijaksanaan Perbankan ini dianggap paling liberal diantara paket kebijaksanaan lainnya. Hal ini bisa dilihat dari isi pakto tersebut yang memuat perubahanperubahan kebijakan mendasar dibidang perbankan, antara lain : dipermudahnya pendirian bank baru maupun pendirian kantor cabangnya, diijinkannya bank asing beroperasi di beberapa kota besar di Indonesia, maupun penurunan reserve requirement dari $15 \%$ menjadi $2 \%$ agar bank dapat dengan maksimal mencari dana masyarakat. Namun deregulasi tersebut telah menghasilkan banyak masalah, karena kurang matang, sehingga pada saat perekonomian Indonesia sedikit memanas (overheated) kondisi perbankan terganggu. Paket kebijaksanaan tersebut menyebabkan banyak masalah karena turunnya tidak disertai dengan ramburambu seperti layaknya suatu paket deregulasi. Setelah beberapa lama deregulasi berjalan dengan peningkatan jumlah bank yang sangat fantastis, namun tanpa memperhatikan ketentuan prudential banking, dan banyaknya bank collapse pada saat situasi ekonomi kurang baik, baru disadari betapa perlunya rambu-rambu peraturan yang harus menyertai. Akhimya diluncurkan paket kebijaksanaan tanggal 28 Februari 1991 sebagai koreksi atas Pakto 1988.

Ketentuan-ketentuan dalam Paket Februari 1991 tersebut mengarah pada prinsip kehati-hatian bank, yakni dengan memberikan beberapa batasan yang harus dipertanggungjawabkan oleh bank, antara lain : Capital Adequacy Ratio minimal 8\%, Loan to Deposit Ratio maksimum $110 \%$, batas maksimum pemberian kredit atau Legal Lending Limit maksimum $10 \%$ dari modal bank untuk nasabah individual dan 30\% untuk nasabah kelompok, serta beberapa ketentuan kesehatan bank yang menyebabkan perbankan mengalami kondisi memprihatinkan. Kondisi ini terutama terjadi pada tahun 1990/1991, ketika penawaran uang meningkat $40 \%$ dan dunia perbankan kebanjiran dana (over liquid), sehingga memberikan kredit seenaknya, tanpa memperhatikan Loan to Deposit Ratio, Capital Adequacy Ratio, maupun Legal Lending Limit. Pada saat pemerintah melakukan kebijaksanaan pengetatan atau tigh money policy pada tahun 1990/1991, perbankan kesulitan uang tunai, akhimya meningkatkan sukü bunga depositonya hingga mencapai $28 \%$ per tahun.

Akibat dari diintrodusimya prudential banking muncul pada tahun 1993 dan awal tahun 1994, sementara bank pemerintah sudah collaps duluan. Sebenamya pada tahun 1994 tersebut kondisi perbankan Indonesia sudah menjadi bagian dari perbankan intemasional, ekonomi kita sudah interlink dengan perekonomian global, sehingga pada saat Federal Reserve (Bank Indonesianya Amerika) menaikkan suku bunga $0,25 \%$ perbankan kita 
ikut panik. Bahkan ketika Federal Reserve menaikkan suku bunga dengan $0,5 \%$, perbankan kita menaikkan bunga dengan $2 \%-3 \%$.

\section{Price Leader}

Sebenamya posisi price leader (penentu harga) dari bank-bank pemerintah sudah dipegang jauh sebelum adanya Pakto 1988. Pada saat itu kekuatan bank pemerintah sangat besar dan dominan, apalagi dengan . memasukkan kekuatan bank sentral yang sangat sering intervensi dalam pasar uang dan menyokong bank-bank pemerintah sebagai bank pelaksananya.

Dominasi perbankan oleh bank pemerintah sudah dipegang bersamaan dengan perkembangan perbankan nasional. Namun sejak Pakto 1988, nampak ada.gejala yang sangat menarik. Serbuan bank swasta yang sangat menggebu dengan jumlah kantor bank dan kantor cabang yang banyak telah menggoyahkan dominasi bank BUMN tersebut, sehingga memperkecil pangsa pasar bank pemerintah baik pangsa kredit maupun pangsa pasar dana masyarakat.

Demikian.pula mengenai posisi bank pemerintah yang semenjak didirikannya selalu menduduki sebagai price leader, kini' juga mulai ada tanda-tanda semakin kecil kekuatannya dalam mempengaruhi pasar uang di Indonesia. Fenomena ini bisa disimak dari beberapa contoh dibawah ini :

Pertama, untuk mengatasi tingginya suku bunga deposito sebagai akibat tigh money policy tahun 1991/ 1992, bank pemerintah sebagai price leader seharusnya bisa mempelopori dengan menurunkan suku bunga depositonya, namun hal ini tidak dilakukannya. Justru yang terjadi adalah kesepakatan dari 28 bank swasta dan 7 bank pemerintah untuk menurunkan suku bunga kredit (waktu itu sering disebut sebagai Konsensus Hilton). Ini menunjukkan bahwa bank pemerintah sudah tidak percaya lagi tehadap posisi price leader yang telah disandangnya.

Kedua, Jika kita tengok peristiwa pada akhir tahun 1991 dimana Bank Indonesia (BI) sebagai penguasa moneter melihat bahwa suku bunga saat itu dianggap terlalu tinggi, sehingga dikhawatirkan akan menghambat laju investasi. Untuk itu BI telah menurunkan tingkat diskonto Sertifikat Bank Indonesia (SBI) dan Surat Berharga Pasar Uang (SBPU). Untuk mendukung polcynya tersebut BI telah mengadakan pendekatan pada bank pemerintah agar menurunkan suku bunganya. Bank pemerintah akhimya menurunkan suku bunga kreditnya antara $1 \%$ hingga $2,5 \%$. Biasanya apabila ada perubahan suku bunga dari bank pemerintah, bank-bank swasta sebagai follower akan segera mengikutnya. Namun kenyataannya saat itu bank-bank. swasta tidak segera mengikuti menurunkan suku bunga kreditnya, mereka saling menunggu bagaimana reaksi bank swasta lainnya. Ini menunjukkan bahwa bank pemerintah sudah bukan sebagai pemimpin harga lagi.

Bahkan beberapa hari sebelum BI menurunkan suku bunganya, ada beberapa bank swasta papan atas yang mendahului menurunkan suku bunga kreditnya. Ini menunjukkan gejala baru yang perlu diperhatikan, karena belum pernah terjadi bank swasta mempunyai inisiatif untuk mempengaruhi tingkat harga (bunga).

Posisi price leader bank pemerintah sebelum deregulasi Oktober 1988 memang bisa kita pahami. Pada saat itu bank pemerintah sangat menguntungkan, selain karena belum tumbuhnya perbankan swasta karena sulit membuka bank baru maupun membuka kantor cabang, bank pemerintah juga mendapat dukungan dana dari BI dengan jumlah yang sangat besar, sehingga persaingan tidak begitu ketat. Dengan demikian bank pemerintah bisa memobilisasi dana masyarakat dengan baik serta mengembangkan kreditnya. Setelah pakto 1988 barulah bank swasta berkembang dengan sangat pesat baik dari segi jumlah kantor bank baru, jumlah cabang yang didirikan, maupun dalam mobilisași dan penyaluran dana.

\section{Pergeseran Kekuatan}

Kalau kita amati, semenjak diluncurkannya Pakto 1988 bank swasta nampak menggebu dalam segala hal, baik dalam memobilisasi dana masyarakat, pemberian kredit, penciptaan produk, maupun perluasan kantor cabang. Sehingga dapat dikatakan deregulasi 27 Oktober 1988 tersebut adalah milik bank swasta, bukan memihak bank pemerintah. Kondisi semacam itu menjadikan posisi bank pemerintah semakin lama akan tergeser oleh peran bank swasta. Pergeseran tersebut bisa dilihat dengan indikator sebagai berikut :

a. Mobilisasi Dana masyarakat

Dalam mobilisasi dana masyarakat misalnya, bisa kita lihat pada Juni tahun 1994 bank swasta devisa masih dibawah bank pemerintah. Bank swasta mampu mengumpulkan dana masyarakat sebesar Rp. 66,734 milyar atau mempunyai pangsa. pasar 41,64 persen sedangkan bank pemerintah mampu mengumpulkan dana lebih tinggi dibanding bank swasta yakni sebesar Rp. 69.432 milyar atau mempunyai pangsa 43,32 persen. Setahun setelah itu yakni posisi juni tahun 1995; pangsa pasar dana masyakarat sudah bergeser pada bank swasta. Dana masyarakat bank swasta meningkat menjadi Rp. 89.843 milyar atau mempunyai pangsa 45,64 persen, sedangkan bank pemerintah mampu mengumpulkan dana masyarakat sebesar Rp. 75.315 milyar atau mempunyai pangsa pasar 38,26 persen. Dengan demikian pangsa pasar bank pemerintah menurun, walauun secara absolut jumlah dana yang dikumpulkan 
meningkat (lihat tabel 1).

\section{Tabel 1}

Mobilisasi Dana Masyarakat

Bank Pemerintah, BPD, dan Bank Swasta

(Juta Rupiah)

\begin{tabular}{|c|c|c|c|c|}
\hline \multirow{2}{*}{ Kelompok Bank } & \multicolumn{2}{|c|}{ Juni 1994} & \multicolumn{2}{|c|}{ Juni 1995} \\
\hline & Jumlah & Pangsa & Jumlah & Pangsa \\
\hline $\begin{array}{l}\text { Bank Pemerintah } \\
\text { Bank Pembangunan }\end{array}$ & $\begin{array}{c}69.432 .128 \\
-\end{array}$ & $43,32 \%$ & 355 & $38,26 \%$ \\
\hline $\begin{array}{l}\text { Daerah } \\
\text { Bank Swasta Devisa } \\
\text { Bank Swasta }\end{array}$ & $\begin{array}{r}5.077 .741 \\
66.734 .227\end{array}$ & $\begin{array}{r}3,17 \% \\
41.64 \%\end{array}$ & $\begin{array}{r}6.612 .823 \\
89.843 .285\end{array}$ & $\begin{array}{r}3,36 \% \\
45,64 \%\end{array}$ \\
\hline $\begin{array}{l}\text { Non Devisa } \\
\text { Bank Asing }\end{array}$ & $\begin{array}{l}9.800 .802 \\
2.650 .382\end{array}$ & $\begin{array}{l}6.12 \% \\
1.65 \%\end{array}$ & $\begin{array}{r}12.821 .386 \\
3.976 .806\end{array}$ & $\begin{array}{l}6,51 \% \\
2,02 \%\end{array}$ \\
\hline Bank Campuran & 6.572 .077 & $4.10 \%$ & 8.284 .485 & $4,21 \%$ \\
\hline . & 196.854 .150 & & 0.267 .356 & \\
\hline
\end{tabular}

Sumber : Peta Keuangan dan Perbankan

Jakarta, 1995

Perkembangan bank swasta ini akan kelihatan sangat mencolok bila kita melihat data tahun 1988, dimana jumlah dana yang dikumpulkan hanya sebesar Rp. 11.167 milyar atau hanya mempunyai pangsa pasar 29,77 persen, sementara bank pemerintah pada waktu yang sama mampu menggalang dana masyarakat sebesar Rp. 22.527 milyar atau pangsa pasar 60,6 persen.

Pergeseran dalam perolehan dana ini dalam sejarah memang baru kali ini terjadi. Hal ini tentunya tidak lepas dari usaha bank swasta dalam memburu dana. Bank swasta dalam memburu dana sangat lincah dan selalu berinovasi dengan menciptakan produkproduk baru yang menarik seperti pemberian bunga tidak berdasar saldo rata-rata setiap bulan, tetapi berbunga harian. Suku bunganya bersaing dengan bank pemerintah, di samping dengan memberikan imingiming hadiah dengan nilai yang cukup besar. Bahkan karena ada kebijaksanaan dimana BUMN boleh mendepositokan dananya ke bank swasta, maka bank swasta berlomba-lomba menarik dana BUMN tersebut agar disimpan dibanknya. Dana BUMN yang semula hanya dimonopoli dan menjadi andalan bank pemerintah, sekarang menjadi rebutan dan akhimya sebagian be hank swasta.

Memang paket 27 Oktober 1988 telah mengubah struktur perbankan nasional. Semula perbankan pemerintah selalu menempati urutan teratas dengan segala fasilitas yang diterima dari pemerintah, kini posisi tersebut harus direlakan diduduki perbankan swasta.

b. Kredit yang diberikan

Pada sektor perkembangan kredit juga terjadi fenomena yang menarik. Seperti terlihat dalam tabel 2 , bahwa pada juni 1994 kredit yang diberikan oleh bank pemerintah sebesar Rp. 94.273 milyar dengan pangsa pasar 49,65 persen, dan setahun setelah itu juni 1995 nilai kredit yang diberikan secara absolut meningkat menjadi 106.641 milyar, tetapi secara relatif justru terjadi penurunan. Pangsa pasar yang bisa diraih turun menjadi 45,84 persen atau turun selitar $9 \%$. Sedangkan nilai kredit perbankan swasta secara relatif menunjukkan kenaikkan yang cukup berarti. semula pada juni 1994 kredit yang diberikan sebesar Rp. 65.879 milyar dengan pangsa pasar juga meningkat menjadi Rp. 86.568 milyar dengan pangsa pasar $37,21 \%$ persen atau pangsa pasarnya meningkat dengan $6 \%$. Apalagi bila dibandingkan dengan tahun 1988, pangsa pasar bank swasta hanya mencapai 25 persen sementara bank pemerintah memimpin dengan pangsa pasar 67 persen. $\mathrm{Hal}$ ini menunjukkan bahwa perkemabngan kredit bank swasta selalu meningkat dengan mantap, sementara pangsa bank pemerintah menurun dan diambil oleh bank swasta.

Tabel 2

Jumlah Kredit yang Disalurkan

Bank Pemerintah, BPD, dan Bank Swasta (Juta Rupiah)

\begin{tabular}{|c|c|c|c|c|}
\hline \multirow{2}{*}{ Kelompok Bank } & \multicolumn{2}{|c|}{ Juni 1994} & \multicolumn{2}{|c|}{ Juni 1995} \\
\hline & Jumlah & Pangsa & Jumlah & Pangsa \\
\hline $\begin{array}{l}\text { Bank Pemerintah } \\
\text { Bank Pembangunan }\end{array}$ & 94.273 .633 & $49,65 \%$ & 106.641 .834 & $45,84 \%$ \\
\hline $\begin{array}{l}\text { Daerah } \\
\text { Bank Swasta Devisa } \\
\text { Bank Swasta }\end{array}$ & $\begin{array}{r}3.729 .720 \\
65.879 .559\end{array}$ & $\begin{array}{r}1,96 \% \\
34,69 \%\end{array}$ & $\begin{array}{r}4.783 .367 \\
86.568 .906\end{array}$ & $\begin{array}{r}2,06 \% \\
37,21 \%\end{array}$ \\
\hline $\begin{array}{l}\text { Non Devisa } \\
\text { Bank Campuran } \\
\text { Bank Asing }\end{array}$ & $\begin{array}{r}10.134 .607 \\
9.379 .726 \\
6.496 .185\end{array}$ & $\begin{array}{l}5,34 \% \\
4,94 \% \\
3,42 \%\end{array}$ & $\begin{array}{r}13.090 .451 \\
13.006 .948 \\
8.565 .625\end{array}$ & $\begin{array}{l}5,63 \% \\
5,60 \% \\
3,68 \%\end{array}$ \\
\hline Total & 189.893 .430 & & 232.657 .131 & \\
\hline
\end{tabular}

Sumber, : Peta Keuangan dan Perbankan Jakarta, 1995

Bila kita simak lebih teliti, besamya kredit yang diberikan oleh bank pemerintah tersebut, karena berhubungan dengan keberanian bank pemeritah dalam mengadakan ekspansi kredit. Dari tabel 1 dan 2, jika dianalisis akan terlihat Loan to Deposit Ratio (LDR) atau perbandingan antara jumlah kredit yang diberikan dengan jumlah dana masyarakat, yang dimiliki bank pemerintah pada juni 1994 sebesar 136\% dan setahun setelah itu LDRnya menunjukkan angka $142 \%$. Besarnya LDR ini menunjukkkan bahwa bank pemerintah berani mengambil resiko yang cukup. besar, dengan konsekwensi tingkat kesehatannya dianggap kurang baik, sebab menurut aturan pruduntial banking LDR maksimal sebesar $110 \%$. 
Sementara bank swasta nampak lebih berhatihati dalam menyalurkan kreditnya, sehingga tidak melanggar ketentuan yang telah digariskan olch Bank Indonesia. LDR yang dimiliki pada Juni 1994 menunjukkan 99 persen, sementara pada juni 1995 menunjukkan angka 96 persen.

\section{c. Analisa Profitabilitas}

Ukuran suatu unit usaha pada dasarnya ada pada seberapa besar laba yang mampu dihasilkan, jika tidak diukur dengan tingkat keuntungan yang mampu dihasilkan, maka analisis tersebut belum bisa menjadi indikator yang baik. Setelah menelaah prestasi bank pemerintah dan bank swasta dari segi mobilisasi dana masyarakat dan kredit yang diberikan, maka perlu kita lihat data yang menujukkan tingkat prestasi ditinjau dari sumbangan keuntungannya. Pada tabel 3 terlihat bahwa temyata tingkat laba yang dihasilkan oleh bank. swasta jauh lebih besar dibanding dengan bank pemerintah. Pada tahun 1994 bank pemerintah memperolah keuntungan sebesar $\mathrm{Rp} 425$ milyar sementara bank swasta mampu mencetak keuntungan Rp. 589 milyar, dan setahun setelah masing-masing meningkat, bank pemerintah mendapat keuntungan Rp, 578 milyar sementara bank swasta menjadi Rp. 796 milyar.

Perlu diingat bahwa keuntungan yang diperoleh oleh bank, bila dikaitkan dengan jumlah kredit yang disalurkan, akan terlihat tingkat efisiensi bank. Bank pemerintah yang memberikan kredit dengan jumlah yang besar, hanya menghasilkan keuntungan yang relatif kecil. Sedangkan bank swasta dengan jumlah kredit yang lebih kecil, ternyata menghasilkan keuntungan jauh lebih besar. Hal ini menunjukkkan tingkat efisiensi bank swasta jauh lebih baik dibanding dengan bank pemerintah.

Tabel 3

Jumlah Laba Yang Dihasilkan

Bank Pemerintah, BPD, dan Bank Swasta (Juta Rupiah)

\begin{tabular}{|c|c|c|c|c|}
\hline \multirow{2}{*}{ Kelompok Bank } & \multicolumn{2}{|c|}{ Juni 1994} & \multicolumn{2}{|c|}{ Juni 1995} \\
\hline & Jumlah & Pangsa & Jumlah & Pangsa \\
\hline $\begin{array}{l}\text { Bank Pemerintah } \\
\text { Bank Pembangunan }\end{array}$ & 425.025 & $31,20 \%$ & 578.876 & $29,02 \%$ \\
\hline Daerah & 53.400 & $3,92 \%$ & 154.168 & $5,22 \%$ \\
\hline $\begin{array}{l}\text { Bank Swasta Devisa } \\
\text { Bank Swasta }\end{array}$ & 589.831 & $43.29 \%$ & 796.480 & $39,92 \%$ \\
\hline Non Devisa & 69.609 & $5,11 \%$ & 113.317 & $5,68 \%$ \\
\hline Bank Asing & $112: 803$ & $8,2 \varepsilon$ & 184.931 & $9,27 \%$ \\
\hline Bank Campuran & 111.777 & $8,20 \%$ & 217.224 & $10,89 \%$ \\
\hline Total & 1.362 .445 & & 1.994 .996 & \\
\hline
\end{tabular}

Sumber : Peta Keuangan dan Perbankan Jakarta, 1995
Tingkat efisiensi bank swasta jauh lebih baik ini tentunya masuk akal, sebab sebagai bank swasta maka manajemen harus dikelola secara profesional, sehingga sumberdaya yang ada digunakan seoptimal mungkin. Sedangkan bank pemerintah yang notabene masih harus mengemban misi sebagai agent of deveopment, dan masih banyak dicampur tangani oleh pemerintah nampaknya sulit untuk bekerja dengan profesional.

\section{Agenda Permasalahan}

Mengelola lembaga perbankan memang tidak mudah, banyak aturan yang harus dipatuhi agar prinsip perbankan yang harus penuh kehati-hatian ini bisa dijalankan dengan baik. Namun kenyataannya masih banyak permasalahan yang dihadapi oleh dunia perbankan. Permasalahan tersebut antara lain :

Pertama, masih banyaknya pelanggaran yang dilakukan oleh bank menyangkut legal lending limit atau Batas Maksimum Pemberian Kredit (BMPK). Hampir setiap bank melanggar prinsip ini, yakni memberikan kredit pada satu pengusaha atau kelompok usaha dengan tertentu dengan jumlah besar. Hal ini sangat berbahaya bila nasabah yang diberi kredit tersebut mengalami kegagalan usaha, maka kreditnya sulit untuk ditagih yang akhirnya macet. Karena jumlahnya besar, mengakibatkan bank mengalami kegoncangan. Oleh karena itu Gubemur BI bertekad untuk memperbaiki posisi BMPK perbankan bahkan beliau juga àkan menuntut pimpinan bank yang melanggar BMPK ini.

$K e d u a$, masalah kredit macet yang semakin tahun semakin menumpuk. Kredit macet ini merupakan masalah yang sangat pelik, yang akan mengganggu operasional bank, dan cenderung memperburuk prestasi bank. Data kredit macet menunjukkkan angka $4,16 \%$ dari total kredit yang diberikan oleh perbankan yakni sebesar Rp. 9.971 milyar. Sedangkan koposisinya bisa dilihat pada tabel 4.

Tabel 4

Jumlah dan Komposisi Kredit Macet (Milyar Rp).

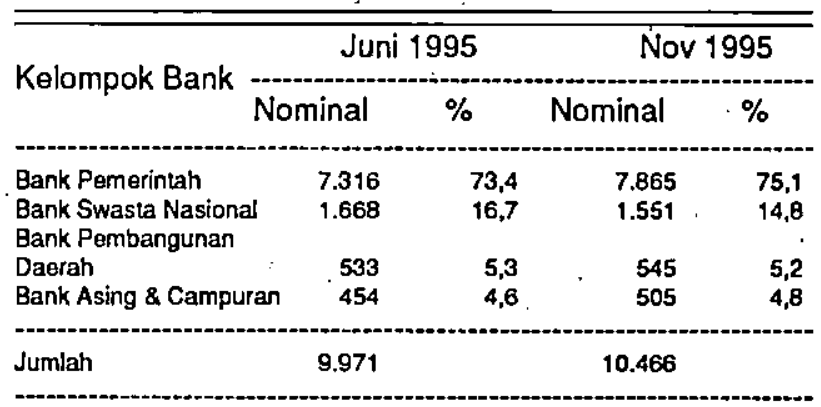

Sumber : Bank Indonesia 
Di samping itu saat ini juga masih terjadi perang tarif antar bank, yang ini bila diteruskan menjadikan kondisi perbankan kurang sehat:

\section{Penutup}

Tidak dapat dipungkiri bahwa Pakto 1988 merupakan kebijaksanaan liberalisasi perbankan yang menyebabkan perubahan mendasar di dunia perbankan. Persaingan antar bank tidak bisa dipungkiri, sehingga bank pemerintah yáng belum siap sumberdaya manusia dan mentalnya mulai tergeser kedudukannya sebagai bank yang nomer satu. Bank pemerintah kalah gesit dibanding dengan bank swasta, yang dalam mengambil kebijaksanaan dan keputușan serba cepat. Sedangkan bank pemerintah dimana para direksinya merupakan subordinasi dari birokrat karena mereka diangkat oleh Menteri Keuangan, bisa menyebabkan terjadinyä campur tangan yang sangat kuat dari pihak birokrat, sehingga kemungkinan seperti kasus Bapindo mudah terjadi. Bank pemerintah yang notabene dalam operasionalnya masih mengemban misi agen pembangunan, bagaimanapun harus bisa segera menyesuaikan diri dengan pesatnya perkembangan perbankan. Untuk itu periu pengelolaan yang profesional, dan campur tangan pihak birokrat sejauh mungkin dihilangkan agar posisi price leader bank pemerintah bisa dipertahankan.

\section{Daftar Pustaka}

Abdullah Ali, Otoritas Moneter Melihat Gejala Baru, Artikel Infobank, No. 193 Desember 1995

Indikator Keuangan dan Perbankan Indonesia, Ekofin Konsulindo Banking and Financial Consultant, 1995

InfoBank, No. 189, September 1995

Laksamana sukardi, Perbankan Indonesia di Persimpangan Jalan, InfoBank, No. 186 Juni 1995

J. Soedrajad Djiwandono, Tantangan Perbankan Indonesia 1996, Artikel, InfoBank, No. 193 Desember 1995

Muchdarsyah Sinungan, Strategi Bank Menghadapi tahun 2000, Rineka Cipta, Jakarta, 1992

Philip C.C. Holberton. Paradogs Baru Dunia Perbankan 1996, Artikel, InfoBank, No. 193 Desember 1995

Roosniati Salihin, Menuju Perbankan Yang Lebih Sehat, Artikel, InfoBank, No. 193 Desember 1995

Winarto soemarto, Sekali Lagi Soal Sumberdaya Manusia, Artikel InfoBank, No. 193 Desember 1995 